\title{
Morphological study of cotton (Gossypium hirsutum L.) varieties against drought tolerance under greenhouse conditions
}

\author{
Ali Ahmad ${ }^{*}$, Zubair Aslam ${ }^{1}$, Korkmaz Bellitürk ${ }^{2}$, Muhammad Usman \\ Ibrahim $^{1}$, Sami-ur-Rehman ${ }^{1}$, Mehwish Nadeem ${ }^{3}$, Kayahan Yilmaz ${ }^{4}$, \\ Umaro Ali ${ }^{5}$ and Ghulam Akbar ${ }^{6}$ \\ 1. Department of Agronomy, University of Agriculture Faisalabad, 38000-Pakistan \\ 2. Department of Soil Science and Plant Nutrition, Faculty of Agriculture, Tekirdag Namık Kemal University, \\ Suleymanpasa Tekirdag-Turkey \\ 3. Department of Botany, University of Agriculture Faisalabad, 38000-Pakistan \\ 4. Department of Feed and Animal Nutrition Science, Faculty of Agriculture, Tekirdag Namık Kemal University, \\ Suleymanpasa Tekirdag-Turkey \\ 5. Department of Plant Breeding and Genetics, Ghazi University, Dera Ghazi Khan-Pakistan \\ 6. Department of Biochemistry, University of Agriculture Faisalabad, 38000-Pakistan \\ *Corresponding author's email: aliahmadsial2643@gmail.com
}

\section{Citation}

Ali Ahmad, Zubair Aslam, Korkmaz Bellitürk, Muhammad Usman Ibrahim, Sami-ur-Rehman, Mehwish Nadeem, Kayahan Yilmaz, Umaro Ali and Ghulam Akbar. Morphological study of cotton (Gossypium hirsutum L.) varieties against drought tolerance under greenhouse conditions. Pure and Applied Biology. Vol. 9, Issue 1, pp696-703. http://dx.doi.org/10.19045/bspab.2020.90075

\begin{tabular}{llll}
\hline \hline Received: 02/09/2019 & Revised: 01/12/2019 & Accepted: 08/12/2019 & Online First: 24/12/2019 \\
\hline \hline
\end{tabular}

\section{Abstract}

Cotton is a vital fiber and oilseed crop badly affected by soil moisture deficit stress. Screening of cotton germplasm is a prerequisite to classify the cotton varieties as a drought sensitive and tolerant. With the aim to separate the distinct genotypes, ten cotton genotypes (FH-142, FH-118, MNH-886, BH-178, VH-259, SLH-317, FH-113, IUB-13, BS-52and NIAB-878 ) were grown under normal moisture and moisture stress environments. One group of seedling was watered at regular intervals (control) and other group was subjected to three consecutive drought cycles. The assessment was done through different morphological parameters (root length, shoot length, root fresh weight, shoot fresh weight, root dry weight, shoot dry weight and lateral root numbers). The leaf chlorophyll contents were also evaluated. The experimental design was Complete Randomized Design (CRD) in factorial way with three replicates. The data obtained was investigated statistically at 5\% probability and Least Significant Difference (LSD) test was used to isolate the significant means (treatment). The results indicated that water stress adversely reduced the values of the above stated parameters excluding root length of some varieties. It is concluded that some genotypes of cotton such as FH-113, IUB-13, BS-52 and NIAB-878 indicated best response against water-deficit environment.

Keywords: Cotton; Morphological; Screening; Seedling; Varieties Introduction

Cotton (Gossypium hirsutum L.) is a highly valuable fiber crop which fulfills the fiber 
needs of half of the world $[1,2]$. It is the most significant source of fiber in the presence of synthetic fibers $[3,4]$. Not only its fiber but also its seed is of highly valuable economically which serves as important raw material for cooking oil, and after oil extraction the residual oil cake is an important source of protein rich feed for livestock [5]. Cotton seed consists of relatively high quality oil and protein in the ratio of $21 \%$ and $23 \%$, respectively [6]. Plastics, rubber, pharmaceuticals, cosmetics, emulsifiers, margarine and soap are the main products of cotton seed oil [7].

Cotton is an important cash crop in the world [8]. Cotton growing farmers depend solely on the income from this cash crop for buying the things and needs of their family [9]. In spite of the fact that the cotton is the most important cash crop for a large proportion of the farmers, the farmers are unable to get more yield than $25-30 \%$ of their yield potential due to drought [8]. Out of all the stress factors which affect the crop yields in the world, drought holds a prominent place which covers $26 \%$ part [10]. When plants from a same cotton variety are passed through drought, they give $50 \%$ low yield as compared to well irrigated cotton plants of the same variety [11]. Agriculture in Pakistan suffers extensive dry spells and drought due to its high dependence on rainfall for irrigation. In recent years, rainfall pattern has changed in Pakistan resulting variation in the onset of rain and its uneven distribution in different areas of the country [12]. Adequate irrigation can increase the cotton production but most of the farmers are deprived of proper irrigation facilities in the country. For small scale farmers, growing drought resistant cotton varieties is the sole method to tackle drought. Selecting different varieties for adaptation in different water deficit areas is the main strategy to develop drought tolerant varieties in breeding programs [13].
Plant Breeders have worked hardly to synthesize drought tolerant cotton varieties i.e., the characteristics of roots play major role in the survival of a plant in drought conditions and root growth is very less affected by the drought conditions but plant height, yield and shoot growth rate are retarded in water deficiency. Plants avoid water deficiency by elongating their root deeper in the soil to reach underground water table [14]. The root elongation is much more at moderate drought but severe drought root length start decreasing. When cotton seedlings are subjected to water deficiency they show elongation in roots but reduction in its diameter [14]. The difference in the measurements of root and shoot length of $G$. hirsutum seedlings shows the difference in the response of different varieties/lines to the water stress condition [15]. The growth of the root in fact indicates the response of a plant to water deficiency [14]. Considerable variation has been observed in tap root length and number of lateral root among exotic germplasm. Useful genetic variation in root growth parameters which are root length (RL), lateral root number (LRN), root fresh weight (RFW), lateral root dry weight (LRDW) and total root dry weight (TRDW) has been observed in the day-neutral converted race stocks (CRS) accessions [16]. The Considerable genetic variability for dry matter accumulation, heat tolerance and root growth exists in the foreign germplasm of G.hirsutum; and that vigorous root growth and number of lateral roots play important role in the adaptation of a cotton plant in water stress conditions [17]. The prior knowledge of correlation among traits discussed above is necessary to start breeding program as it provides the chance to a desirable trait to be selected [18]. There is significant positive correlation among root length, lateral root number, total dry root weight, and shoot dry weight [19]. 
As there is no information about the cotton genotypes grown in Pakistan regarding the performance in water stress conditions so, there is dire need to screen the cotton genotypes for drought tolerance. This research was conducted to identify drought tolerant cotton varieties out of 10 genotypes which could show vigorous growth and give maximum productivity during dry spells.

\section{Materials and methods}

The study was conducted during kharif season in 2017 at Green House of University of Agriculture Faisalabad (altitude $184 \mathrm{~m}$, latitude $31.40^{\circ} \mathrm{N}$, longitude $73.05^{\circ} \mathrm{E}$ ). Ten varieties (FH-142, FH-118, MNH-886, BH178, VH-259, SLH-317, FH-113, IUB-13, BS-52 and NIAB-878) were planted in plastic tubes $130 \times 36 \mathrm{~cm}$ size. These plastic tubes were subjected in the PVC pipes $120 \times 30 \mathrm{~cm}$ size to keep straighten the plastic tubes. Plastic tubes were filled with fine sand (easy to wash roots) to grow the cotton seedlings. Ten tubes of each genotype were planted by seeding five seeds per tube and thinning of seedlings to one plant per tube were carried out 15 days post emergence. The temperature kept was $30-35^{\circ} \mathrm{C}$ and $28-32^{\circ} \mathrm{C}$ with $50-55 \%$ and $60-70 \%$ relative humidity at day and night, respectively. The plants were grown under water stressed and non-stressed conditions. Each tube was watered in equal amount and fertilized by NPK (20-20-20+TE) Faster (Italy), Agrium Enterprises, Multan for normal growth. Fertilization was performed by aspiration during watering. All plants in tubes were watered and fertilized in accordance with the procedure described above until the plants reached the first true leaf stage. Subsequently, the tubes were distributed randomly in two groups, each containing five tubes of each genotype. One group of seedling was watered at regular intervals (control) and other group was subjected to three consecutive drought cycles. This drought stressed regime was initiated by first with holding water when the plants reached the first true leaf stage. Each drought cycle contained withholding water for 15 days. Plants were watered to field capacity $12 \mathrm{~h}$ after visual signs of wilting. At the end of third drought cycle from each group plants were harvested. Roots were washed free of sand and then spread on paper sheet for determination of the following parameters:

$1)$. Root length $(\mathrm{cm})$ and shoot length was measured with the help of meter rod. 2). Root fresh weight and shoot fresh weight (g plant ${ }^{-}$

$\left.{ }^{1}\right)$ : Roots were cut at the base of the shoot, and then root fresh weight (g) was taken. Furthermore, shoots were separated from roots to calculate shoot fresh weight (g). 3). Root dry weight (g plant ${ }^{-1}$ ): Root material was placed in an oven at $70^{\circ} \mathrm{C}$ for 72 hours to get constant dry weight then root dry weight (g) was calculated. 4). Shoot dry weight (g plant ${ }^{-1}$ ): Shoot material was placed in an oven at $70^{\circ} \mathrm{C}$ for 72 hours to get constant dry weight then root dry weight (g) was calculated. 6): Lateral root number (LRN)

7): Leaf chlorophyll contents (SPAD value): Chlorophyll contents of the leaves were determined by using SPAD instrument (model SPAD-502; Minolta Corp., Ramsey, $\mathrm{NJ})$

Statistical analysis: The recorded data was statistically analyzed via Fisher's analysis of variance (ANOVA) technique. LSD test was used $(\mathrm{p} \leq 0.05)$ to compare significant treatments means using Statistic version 8.1(Analytical Software (C, 1985-2005).

\section{Results}

The observed data for root and shoot length of ten cotton varieties indicated that drought caused considerably decline in roots and shoots length of cotton varieties. However, some varieties showed good response against water stress. Under drought conditions, BS$52(128.53 \mathrm{~cm})$ showed tremendous increase in root length followed by $(124 \mathrm{~cm})$, IUB-13 (111.83), FH-113 (118.20 cm), SLH-317 (112.37cm), BH-178 (106.77cm), MNH-886 $(97.67 \mathrm{~cm}) \quad$ FH-118 (93.33cm), VH-259 (91.67) and $\mathrm{FH}-142(85.80 \mathrm{~cm})$ showing 
drought tolerance characteristics. Longest root length was observed for BS-52 (132.47 cm), NIAB-878 (126.03), FH-113 $(124.17 \mathrm{~cm})$, IUB-13 (121.73 cm) while grown under irrigated condition. Shoot length shows the growth of plants. Higher the shoot length, means more photosynthates accumulation due to extensive canopy. Highest shoot length was observed in genotype BS-52 $(23.667 \mathrm{~cm})$ under water deficit environment. However, root and shoot length of different genotypes are more under well-watered environment than drought conditions because nutrients and water uptake reduced when soil moisture is less. Roots fresh weight of ten cotton genotypes grown under drought condition were less as compared to the genotypes grown under normal condition. However, the fresh weight of root and shoot were significantly higher in genotype BS-52 $(23.507 \mathrm{~cm})$ under wellwatered and water deficit environment. Less root and shoot fresh weights were observed in FH-142 and VH-259 (Table 1).

Table1. Effect of water deficit stress (DD) on root length, shoot length, root fresh weight and shoot fresh weight of ten cotton varieties

\begin{tabular}{|c|c|c|c|c|c|c|c|c|}
\hline \multirow{2}{*}{$\begin{array}{l}\text { Cotton } \\
\text { Varieties }\end{array}$} & \multicolumn{2}{|c|}{ Root length (cm) } & \multicolumn{2}{|c|}{$\begin{array}{l}\text { Shoot length } \\
\text { (cm) }\end{array}$} & \multicolumn{2}{|c|}{$\begin{array}{c}\text { Root fresh weight } \\
\text { (g) }\end{array}$} & \multicolumn{2}{|c|}{$\begin{array}{l}\text { Shoot fresh weight } \\
\text { (g) }\end{array}$} \\
\hline & WW & DD & WW & DD & WW & DD & WW & DD \\
\hline \multirow{2}{*}{ FH-142 } & \multirow{2}{*}{$85.40 \mathrm{M}$} & 85.80 & 17.500 & 17.367 & 12.313 & 12.167 & 14.0333 & 12.7800 \\
\hline & & LM & KLM & KLM & GHI & $\mathrm{HI}$ & $\mathrm{HI}$ & K \\
\hline \multirow{2}{*}{ FH-118 } & 101.63 & \multirow{2}{*}{$93.33 \mathrm{JK}$} & 21.400 & 16.533 & 13.330 & 13.043 & 14.4333 & 13.3533 \\
\hline & HI & & $\mathrm{H}$ & LM & FGH & FGHI & $\mathrm{GH}$ & $\mathrm{J}$ \\
\hline \multirow{2}{*}{ MNH-886 } & 106.07 & \multirow{2}{*}{$97.67 \mathrm{IJ}$} & 19.333 & 18.167 & 13.800 & 13.403 & 15.2633 & 13.9733 \\
\hline & $\mathrm{GH}$ & & IJ & JKL & FG & FGH & $\mathrm{E}$ & HI \\
\hline \multirow{2}{*}{ BH-178 } & \multirow{2}{*}{$91.80 \mathrm{JK}$} & 106.77 & 21.600 & 16.367 & 12.617 & 12.563 & 14.2800 & 13.0400 \\
\hline & & $\mathrm{FGH}$ & $\mathrm{GH}$ & M & $\mathrm{GHI}$ & $\mathrm{GHI}$ & GHI & $\mathrm{J}$ \\
\hline \multirow{2}{*}{ VH-259 } & \multirow{2}{*}{$84.00 \mathrm{M}$} & 91.67 & 19.000 & 18.033 & 12.077 & & 14.0667 & 12.7833 \\
\hline & & $\mathrm{KL}$ & JK & JKLM & HI & 01 & $\mathrm{HI}$ & $\mathrm{K}$ \\
\hline \multirow{2}{*}{ SLH-317 } & 106.90 & 112.37 & 25.033 & 20.967 & \multirow{2}{*}{$14.300 \mathrm{~F}$} & \multirow{2}{*}{$14.240 \mathrm{~F}$} & 16.4633 & 13.9033 \\
\hline & FGH & $\mathrm{EF}$ & $\mathrm{DE}$ & $\mathrm{HI}$ & & & $\mathrm{D}$ & \\
\hline \multirow{2}{*}{ FH-113 } & 124.17 & 118.20 & 29.667 & 23.167 & 32.727 & & 17.8267 & 17.2333 \\
\hline & $\mathrm{BCD}$ & $\mathrm{DE}$ & B & FG & 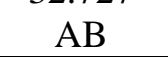 & $7 \mathrm{D}$ & B & C \\
\hline \multirow{2}{*}{ IUB-13 } & 111.83 & 121.73 & 26.933 & 21.033 & \multirow{2}{*}{$18.050 \mathrm{D}$} & \multirow{2}{*}{$16.110 \mathrm{E}$} & 16.8367 & 14.6433 \\
\hline & $\mathrm{FG}$ & $\mathrm{CD}$ & $\mathrm{C}$ & $\mathrm{HI}$ & & & $\mathrm{CD}$ & $\mathrm{FG}$ \\
\hline \multirow{2}{*}{ BS-52 } & \multirow{2}{*}{$132.47 \mathrm{~A}$} & 128.53 & 31.500 & 23.667 & \multirow{2}{*}{$33.507 \mathrm{~A}$} & 31.433 & 18.8200 & 19.0467 \\
\hline & & $\mathrm{AB}$ & A & EF & & $\mathrm{BC}$ & A & A \\
\hline \multirow{2}{*}{ NIAB-878 } & 126.03 & 124 & 25.767 & 21.533 & \multirow{2}{*}{$31.000 \mathrm{C}$} & \multirow{2}{*}{$18.123 \mathrm{D}$} & 17.9267 & 15.0200 \\
\hline & $\mathrm{BC}$ & $\mathrm{BCD}$ & $\mathrm{CD}$ & $\mathrm{GH}$ & & & B & EF \\
\hline
\end{tabular}

Dry root weight, dry shoot weight, lateral root numbers and chlorophyll contents of ten cotton cultivars represent the health and growth status of plant. More dry weight were detected in BS-52 (10.047 g) and FH-113 (7.560 g) grown under normal environment as compared to these genotypes which were grown under drought environment. Overall, BS-52, FH-113, NIAB-878 and IUB-13 performed best both under drought as well as irrigated conditions. More the number of lateral roots, more will be water and nutrients uptake and plants ability to withstand the drought environment. A decrease in chlorophyll contents of leaf reduces the absorption of solar radiation that resulted into decrease in photosynthetic efficiency which effects overall growth of plants. Higher 
chlorophyll contents were found in BS-52 (52.133), FH-113 (46.967), IUB-13

(41.867) and NIAB-878 (45.100) under drought stress environment while FH-118
(36.433) and FH-142 (32.533) showed less chlorophyll contents (Table 2).

Table 2. Effect of water deficit stress (DD) on root dry weight, shoot dry weight, lateral root numbers and chlorophyll contents of eight cotton varieties

\begin{tabular}{|c|c|c|c|c|c|c|c|c|}
\hline \multirow{2}{*}{$\begin{array}{l}\text { Cotton } \\
\text { Varieties }\end{array}$} & \multicolumn{2}{|c|}{ Root dry weight (g) } & \multicolumn{2}{|c|}{$\begin{array}{l}\text { Shoot dry } \\
\text { weight (g) }\end{array}$} & \multicolumn{2}{|c|}{$\begin{array}{c}\text { Lateral root } \\
\text { numbers }\end{array}$} & \multicolumn{2}{|c|}{$\begin{array}{c}\text { Chlorophyll } \\
\text { contents (SPAD } \\
\text { Value) } \\
\end{array}$} \\
\hline & WW & DD & WW & DD & WW & DD & $\mathbf{W W}$ & DD \\
\hline FH-142 & $\begin{array}{c}1.950 \\
\text { GHI }\end{array}$ & $0.407 \mathrm{M}$ & $\begin{array}{c}2.1867 \\
\text { KL }\end{array}$ & $\begin{array}{c}1.5000 \\
\mathrm{~N}\end{array}$ & $9.767 \mathrm{M}$ & $6.500 \mathrm{Q}$ & $\begin{array}{c}39.667 \\
\text { FGH }\end{array}$ & $\begin{array}{c}32.533 \\
\text { I }\end{array}$ \\
\hline FH-118 & $\begin{array}{l}1.570 \\
\text { IJKL }\end{array}$ & $\begin{array}{c}1.187 \\
\text { IJKLM }\end{array}$ & $\begin{array}{c}3.7067 \\
\text { GH }\end{array}$ & $\begin{array}{c}2.0533 \\
\mathrm{~L}\end{array}$ & $\begin{array}{c}14.800 \\
\text { HI }\end{array}$ & $\begin{array}{c}10.200 \\
\mathrm{M}\end{array}$ & $\begin{array}{c}40.733 \\
\text { EFG }\end{array}$ & $\begin{array}{c}36.433 \\
\text { GHI }\end{array}$ \\
\hline MNH-886 & $\begin{array}{l}1.843 \\
\text { HIJK }\end{array}$ & $\begin{array}{l}1.567 \\
\text { IJKL }\end{array}$ & $\begin{array}{c}4.0733 \\
F\end{array}$ & $\begin{array}{c}2.3433 \\
\text { JK }\end{array}$ & $\begin{array}{c}14.033 \\
\text { GH }\end{array}$ & $10.633 \mathrm{~L}$ & $\begin{array}{c}45.433 \\
\mathrm{DE}\end{array}$ & $\begin{array}{c}39.633 \\
\text { FGH }\end{array}$ \\
\hline BH-178 & $\begin{array}{l}1.567 \\
\text { IJKL }\end{array}$ & $\begin{array}{c}0.937 \\
\text { JKLM }\end{array}$ & $\begin{array}{c}4.8000 \\
\mathrm{G}\end{array}$ & $\begin{array}{c}1.7300 \\
\mathrm{M}\end{array}$ & $14.633 \mathrm{I}$ & $9.300 \mathrm{O}$ & $\begin{array}{c}42.467 \\
\text { DEF }\end{array}$ & $\begin{array}{c}36.433 \\
\text { GHI }\end{array}$ \\
\hline VH-259 & $\begin{array}{l}0.890 \\
\text { KLM }\end{array}$ & $\begin{array}{c}0.690 \\
\text { LM }\end{array}$ & $\begin{array}{c}3.5333 \\
\mathrm{H}\end{array}$ & $\begin{array}{c}1.7033 \\
\mathrm{MN}\end{array}$ & $\begin{array}{c}11.133 \\
\mathrm{~K}\end{array}$ & $7.367 \mathrm{P}$ & $\begin{array}{c}37.900 \\
\text { FGH }\end{array}$ & $\begin{array}{c}34.533 \\
\text { HI }\end{array}$ \\
\hline SLH-317 & $\begin{array}{c}2.693 \\
\text { EFGH }\end{array}$ & $\begin{array}{c}1.860 \\
\text { HIJ }\end{array}$ & $\begin{array}{c}4.2833 \\
\text { EF }\end{array}$ & $\begin{array}{c}2.5500 \\
\mathrm{~J}\end{array}$ & $\begin{array}{c}14.233 \\
\mathrm{G}\end{array}$ & $11.667 \mathrm{~J}$ & $\begin{array}{c}45.233 \\
\mathrm{DE}\end{array}$ & $\begin{array}{c}42.600 \\
\text { DEF }\end{array}$ \\
\hline FH-113 & $7.560 \mathrm{~B}$ & $\begin{array}{c}3.287 \\
\mathrm{DE}\end{array}$ & $\begin{array}{c}5.0367 \\
\mathrm{~B}\end{array}$ & $\begin{array}{c}4.6600 \\
\mathrm{C}\end{array}$ & $15.400 \mathrm{E}$ & $21.000 \mathrm{~B}$ & $56.067 \mathrm{~B}$ & $\begin{array}{c}46.967 \\
\text { CD }\end{array}$ \\
\hline IUB-13 & $\begin{array}{l}2.140 \\
\text { FGHI } \\
\end{array}$ & $3.000 \mathrm{EF}$ & $\begin{array}{c}4.4333 \\
\text { DE } \\
\end{array}$ & $\begin{array}{c}3.0167 \\
\mathrm{I}\end{array}$ & $14.727 \mathrm{~F}$ & $11.767 \mathrm{~J}$ & $55.000 \mathrm{~B}$ & $\begin{array}{c}41.867 \\
\text { DEF }\end{array}$ \\
\hline BS-52 & $\begin{array}{c}10.047 \\
\mathrm{~A} \\
\end{array}$ & $4.193 \mathrm{D}$ & $\begin{array}{c}6.000 \\
\mathrm{~A}\end{array}$ & $\begin{array}{c}5.0033 \\
\mathrm{~B} \\
\end{array}$ & $\begin{array}{c}22.067 \\
\mathrm{~A}\end{array}$ & $15.667 \mathrm{D}$ & $\begin{array}{c}65.000 \\
\mathrm{~A}\end{array}$ & $\begin{array}{c}52.133 \\
\mathrm{BC}\end{array}$ \\
\hline NIAB-878 & $6.357 \mathrm{C}$ & $\begin{array}{c}2.887 \\
\text { EFG }\end{array}$ & $\begin{array}{c}4.6167 \\
\text { CD }\end{array}$ & $\begin{array}{c}4.4933 \\
\text { CDE }\end{array}$ & $17.867 \mathrm{C}$ & $14.900 \mathrm{~F}$ & $53.667 \mathrm{~B}$ & $\begin{array}{c}45.100 \\
\text { DE }\end{array}$ \\
\hline
\end{tabular}

\section{Discussion}

Various reports have declared physiological and growth response of different cotton genotypes in water-deficit environment under field conditions in both humid and arid environments and in growth chamber $[18,20$ 22]. However, this study on morphological responses of different cotton genotypes were conducted under greenhouse conditions to assess the drought resistance genotypes. To survive the drought stress, the plants uses two key strategies of drought tolerance and drought escape. During drought escape, plant shortens its growth period by inducing early flowering. But, this reduction in growth length results in less economic yield in indeterminate plants e.g. cotton [23].

Drought tolerance is plants ability to conserve high water contents for proper functioning i.e. drought avoidance and capability of plant endure metabolic function at less water condition i.e. drought resistance. Later rarely occur in crops. The water balance in plants can maintain due to their own physiological and morphological characteristics by reducing water loss through transpiration or enhance water absorbance due to deep and extensive root system [22].

This study revealed that root length, shoot length, fresh weight and dry weight of root and shoot, lateral roots and chlorophyll 
contents of FH-142, FH-118, MNH-886, BH178, VH-259, SLH-317, FH-113, IUB-13, BS-52 and NIAB-878 were less under drought condition as compared to these genotypes grown under irrigated condition $[22,24,25]$. The reason behind this is that the stomatal closure due to decrease in available water reduces the transpiration and carbon dioxide absorption. This leads to reduction in photosynthesis that results in low growth rate. This is also because of the diversion of energy and photosynthetic assimilates to defensive molecules to combat the water stress. The number of lateral roots offered the better yield of crop as due to a greater number of lateral roots and root mass. Plants extract more water during stress to maintain the stomatal conductance that result into higher photosynthesis. This is also related to shoot fresh and shoot dry weight of plants as more lateral roots, the more water uptake for photosynthesis and increase the fresh and dry weight of shoot [17].

Comparable to the other studies, the findings of our study also showed that the depth and growth of rooting have significant implication for plant ability to endure drought [26-30]. Deep and more lateral roots enable the plants to resist the drought by keeping higher water potential and water uptake due to their denser root system. So, some genotypes of cotton such as FH-113, IUB-13, BS-52 and NIAB-878 indicated best response against water-deficit environment.

\section{Conclusion}

Under drought condition, BS-52 $(128.53 \mathrm{~cm})$ showed tremendous increase in root length followed by NIAB-878 $(124 \mathrm{~cm})$, IUB-13 $(111.83 \mathrm{~cm})$, FH-113 (118.20 cm), SLH-317 $(112.37 \mathrm{~cm}), \mathrm{BH}-178(106.77 \mathrm{~cm}), \mathrm{MNH}-$ $886(97.67 \mathrm{~cm}) \mathrm{FH}-118(93.33 \mathrm{~cm}), \mathrm{VH}-259$ $(91.67 \mathrm{~cm})$ and $\mathrm{FH}-142 \quad(85.80 \mathrm{~cm})$ demonstrated the drought tolerance characteristics. Longest root length was observed for BS-52 (132.47 cm), NIAB-878 $(126.03 \mathrm{~cm})$, FH-113 (124.17cm), IUB-13
$(121.73 \mathrm{~cm})$ while grown under irrigated condition, the fresh weight of root and shoot were significantly higher in genotype BS-52 $(23.507 \mathrm{~cm})$ under well-watered and water deficit environment. The Less root and shoot fresh weights were observed in FH-142 and VH-259. More dry weight were detected in BS-52 (10.047 g) and FH-113 (7.560 g) grown under normal environment as compared to these genotypes which were grown under drought environment. Overall, BS-52, FH-113, NIAB-878 and IUB-13 performed best both under drought as well as irrigated condition. Higher chlorophyll contents were founded in BS-52 (52.133), FH-113 (46.967), IUB-13 (41.867) and NIAB-878 (45.100) under drought stress environment while FH-118 (36.433) and FH142 (32.533) showed less chlorophyll contents. It is concluded that some genotypes of cotton such as FH-113, IUB-13, BS-52 and NIAB-878 indicated best response against water-deficit environment

\section{Authors' contributions}

Conceived and designed the experiment: SU Rehman \& G Akbar, Performed the experiment: SU Rehman \& G Akbar, Analyzed the data: A Ahmad \& K Bellitürk, Contributed reagents/ materials/ analysis tools: Z Aslam \& K Yilmaz, Wrote the paper: M Nadeem, U Ali \& MU Ibrahim

\section{References}

1. Pretorius MM (2009). Evaluation of irrigated cotton cultivars in South Africa (MSc. Thesis). University of the Free State, South Africa. Retrieved from http://www.etd.uovs.ac.za/ETDdb/these s/available/etd.

2. Poehlman JM \& Sleper DA (1995). Breeding field crops. Ames, Iowa. Iowa State University Press

3. Sunilkumar G, Campbell LM, Puckhaber L, Stipanovic RD \& Rathore KS (2006). Engineering cotton seed for use in human nutrition by tissuespecific reduction of toxic gossypol. Texas A \& 
M University. Retrieved from http://www.pnas.org/content/103/48/18 054

4. Martin JH, Waldren RP \& Stamp DL (2006). Principles of field crop production. New Jersey. Pearson Prentice Hall.

5. Food and Agriculture Organization of the United Nations (FAO) (1994). Cotton pests and their control in the near east. Rome: Food and Agriculture Organization of the United Nations.

6. Rathore KS (2007). Reducing gossypol in cottonseed may improve human nutrition. Texas A \& M University, College Station, TX. Retrieved from http://www.isb.vt.edu/articles/jul0702.ht m.

7. United States Department of Agriculture (USDA) (2008). Oilseeds: World Markets and Trade. Retrieved from http://www.fas.usda.gov/.../oilseedsworld-market.

8. Ministry of Agriculture and Food Security (MoAFS) (2006). Cotton production in Malawi: Country report presented at the $65^{\text {th }}$ international cotton advisory committee plenary meeting, 11 15 September 2006, Goiania, Brazil. Lilongwe: Ministry of Agriculture and Food Security.

9. Fortucci P (2002). The contributions of cotton to economy and food security in developing countries. Retrieved from http://www.icac.org/meetings/cgtnconf/documents/11-fortucci.pdf.

10. Farshadfar E, Jalali S \& Saeidi M (2012). Introduction of a new selection index for drought tolerance in common wheat (Triticum aestivum L.). Eur J Expt Biol 2(4): 1181-1187.

11. Brito GG, Sofiatti V, Lima MMA, Carvalho LP \& Filho JLS (2011). Physiological traits for drought phenotyping in cotton. Acta Sci Agron 33: 117-125.
12. Ministry of Mines, Natural Resources and Environment (2006). Malawi's National Adaptation Programmes of Action (NAPA). ( $1^{\text {st }}$ Ed.). Lilongwe, Malawi: Environmental Affairs Department, Ministry of Natural Resources, Energy and Environment.

13. Monneveux P \& Ribaut JM (2011). Drought phenotyping in crops: from theory to practice. Retrieved from http://www.integratedbreeding.net/drou ght-phenotyping-crops-theorypractice.

14. Basal H, Smith CW, Thaxton PS \& Hemphill JK (2005). Seedling drought tolerance in upland cotton. Crop Sci 45: 766-771.

15. Iqbal K (2010). The potential for breeding upland cotton under limited water conditions ( $\mathrm{PhD}$ thesis). University of Agriculture, Faisalabad, Pakistan. Retrieved from http://www.prr.hec.gov.pk/Thesis/2295. pdf.

16. Basal H \& Unay A (2006). Water stress in cotton (Gossypium hirsutum L.). Ege Üniv Ziraat Fak Derg 43(3): 101-111.

17. Kohel RJ \& Lewis CF (1984). Cotton. Wisconsin. Crop Sci Soc America, Inc, Publishers.

18. Ali MA, Jabran K, Awan SI, Awan A, Abbas A, Ullah E, Acet T, Farooq J \& Rehman A (2011). Morphophysiological diversity and its implications for improving drought tolerance in grain sorghum at different growth stages. Austr J Crop Sci 5(3): 311-320.

19. Radin, J.W. \& Ackerson RC (1981). Water relation of cotton plants under nitrogen deficiency. III. Stomatal conductance, photosynthesis and abscisic acid accumulation. Plant Physiol 67: 115-119.

20. Loffroy O, Hubac C \& Vieira JBDS (1983). Effect of temperature on drought 
resistance and growth of cotton plants. Physiol. Plant 59: 297-301.

21. Ball RA, Derrick MO \& Mauromoustakos A (1994). Growth dynamics of cotton plant during waterdeficit stress. Agron J 86: 788-795.

22. Pace PF, Cralle HT, El-Halawany SHM, Cothren JT \& Senseman SA (1999). Drought induced changes in shoot and root growth of young cotton plants. $J$ Cotton Sci 3: 183-187.

23. Al-Hamdani, SH \& Barger TW (2003). Influence of water stress on selected physiological responses of three sorghum genotypes. Italy J. Agron 7: 1522.

24. Pettigrew WT (2004). Moisture deficit effects on cotton lint yield, yield components and boll distribution. Agron J 96: 377-383.

25. Pettigrew, WT (2004). Physiological consequences of moisture deficit stress in cotton. Crop Sci 44: 1265-1272.
26. Hannon, N. \& Bradshaw AD (1968). Evolution of salt tolerance in two contrasting species of grass. Nature 220: 1342-1343.

27. Ahmad, I. and Wainwright SW (1977). Tolerance to salt, partial anaerobiosis and osmotic stress in Agrostis stolonifera. New Phytol 79: 605-612.

28. Leim, ASN Hendriks A, Kraal H \& Loenen M (1985). Effects of deicing salt on roadside grasses and herbs. Plant Soil 84: 299-310.

29. Ashraf M, McNeilly T \& Bradshaw AD (1986). Heritability of $\mathrm{NaCl}$ tolerance at the seedling stage in the seven grass species. Euphytica 35: 935-940.

30. Nguyen HT, Babu RC \& Blum A (1997). Breeding for drought resistance in rice physiology and molecular genetics considerations. Crop Sci 37: 1426-1434. 